\title{
A Contrastive Analysis of Interrogative Sentences in English and Indonesian
}

\author{
Mashlihatul Umami \\ Universitas Negeri Semarang \\ Kampus Sekaran, Kel. Sekaran, Kec. Gunung Pati, Semarang \\ umamie@gmail.com
}

\begin{abstract}
The aim of this paper is to investigate the forms of questions in English and Indonesian in order to identify the similarities and differences between them. CA may look at linguistic structures in a twofold way: predictability power and wash back effect (Cheng, Watanabe \& Curtis, 2004). The former deals with foreseeing the areas of problems the English learners may commit and the latter refers to the effect of diagnostic value of CA on improvement of teaching processes. In this case, the researcher emphasizes her study in analyzing CA based on the first perspective; this study focuses on interrogative sentences which are in the form of questions which play an important role in learning English among junior English students. This study has found the differences and similarities between Indonesian and English. Recognizing this will contribute to the accuracy of English questions made by the students.
\end{abstract}

Key words: Interrogative sentences; English; Indonesian; Contrastive analysis, accuracy 
A Contrastive Analysis of Interrogative Sentences in English and Indonesian

\begin{abstract}
Abstrak
Tujuan dari artikel ini adalah untuk menginvestigasi tentang bentuk bentuk kalimat tanya yang ada dalam bahasa Inggris dan bahasa Indonesia untuk mengidentifikasi kesamaan dan perbedaan diantara dua bahasa tersebut. Kajian tentang Analisis kontrastive melihat struktur kebahasaan melalui dua cara yaitu: 'predictability power dan waschback effect' (Cheng, Watanabe \& Curtis, 2004). Cara yang pertama dengan jalan memperkirakan permasalahan permasalahan yang dihadapi oleh pembelajar bahasa dan yang kedua berhubungan dengan pengaruh atau efek penilaian pada peningkatan proses belajar mengajar. Dalam hal ini, peneliti menekankan studinya dalam menganalisis perbedaan berdasarkan perspective yang pertama, kajian studi ini fokus pada kalimat Tanya yang berperan penting dalam pembelajaran bahasa Inggris pada sekolah menengah pertama .Studi ini menemukan perbedaan dan persamaan kalimat tanya pada bahasa Indonesia dan bahasa Inggris. Kedepan hasil dari kajian ini diharapkan dapat memberikan kontribusi spesifik bahwa pemahaman tentang hal tersebut akan meningkatkan ketepatan kalimat Tanya yang disusun oleh para siswa.
\end{abstract}

\title{
Introduction
}

Contrastive analysis of two languages which deals with the similarities and differences in terms of linguistic structures has been studied since the 1940s. It could be a useful predictor of where second language students would likely encounter problems in learning a second language (Gorjian, et.al: 2012). It stood to reason that if certain elements of a second language differed greatly from the students' native language, that student would likely encounter difficulties (Schackne: 2002). Nord (1991) argued that linguistic problems arise from differences of structure in the vocabulary and syntax of second language (SL) and target language. Some of these problems may be caused by what Newmark (1988) calls "false friends" or by situations of one-to many or one to zero 
equivalence. These problems can also be caused by lack of grammar knowledge in the Source language (SL) or the Target Language (TL) (Nord: 1991). Based on the Schackne's (2002) definition by focusing on the differences existing in native and target language, we can predict the difficulties the learners may encounter in learning the target language. Moreover, as Brown (2007) stated, before the learner becomes familiar with the system of the second language, the native language is the only linguistic system. Therefore, not having enough knowledge in this sense will lead learners to use their own system of syntax in the TL and this interference(s) makes them erroneous.

Since ever the emergence of contrastive analysis up to now, many researchers (Schackne: 2002) have used this technique to identify the areas of difficulties for second and foreign language learners. However, a linguistic item that is rarely compared and contrasted between these two languages is question or making question. Therefore, this paper want to study interrogative sentences in English and Indonesian contrastively.

According to Bieber, (1999: 211), questions are many times more common in conversation than in writing. According to Webber (1994: 226), questions create anticipation, arouse interest, challenge the reader into thinking about the topic of the text, and have a direct appeal in bringing the second person into a kind of dialogue with the writer, which other rhetorical devices do not have to the same extent. Questions have been classified differently by researchers and they have his/her own way to classify them.

There are many types of interrogative sentences in English. Its characteristics are: it is used with a rise in pitch, question mark (?), and 
A Contrastive Analysis of Interrogative Sentences in English and Indonesian

has function for asking information. Frank (1972:88) stated that interrogative sentences in English are divided into three types, Yes / No Questions, which is started by auxiliary verb and modal eliciting the answer yes or no. Interrogative-Words/ information Questions functioning as asking for information. The question is usually formed by question words such as: what, where, why, who, when, and how. Finally is tag question; it is added by to be and auxiliary verbs in the end of the sentences (Bieber: 1999, 157), they transform declarative into interrogative sentences and its function is giving an assertion to the listeners.

Meanwhile, interrogative sentences in Indonesian are also varied too. Its characteristics are: it is used with a rise in pitch, using question mark (?), partikel-kah (suffix-kah) or apakah (what), and for asking information. Keraf (1991:204) said that interrogative sentences are divided to three categories, firstly is kalimat tanya total (total questions), it is an interrogative sentences functioning for asking complete information (Keraf: 1991:204). These sentences are answered by " $Y a$ " (Yes) or "Tidak" (No) and it is usually use question word "apakah" (what) or "partikel-kah" (suffix-kah). Secondly is kalimat tanya parsial (partial questions), it is an interrogative sentences answering the questions based on the question words (Muslich: 1990, 90). This sentence usually use question words, such as siapa (who), berapa (how much/many), kapan (when), dimana (where), bagaimana (how), apa (what), and mengapa (why). Thirdly is Kalimat tanya rhetoris (Rhetorical questions) that is interrogative sentences requiring no answers (Keraf: 1991:205). This is usually used in language style, speeches or conversations that listeners have known the answers of the 
questions.

The corpus data is the manuscript of recording from dialog or conversation of English Toolkit for MTsN (Islamic Junior High School). The researcher uses one manuscript of English and Indonesian to be analyzed. In this study, I will use Frank (1972) and Keraf (1991)'s classification as a knife of analysis.

The following is the data taken from the corpus:

Interrogative Sentences in English.

Table 1.1

Yes or No Questions with auxiliary verb

\begin{tabular}{|l|l|l|l|}
\hline Auxiliary & \multirow{2}{*}{ Sentences } & Answers & positive \\
\hline Do & $\begin{array}{l}\text { Do you have a } \\
\text { book? }\end{array}$ & Yes, I do & Negative \\
\hline Does & $\begin{array}{l}\text { Does she has a } \\
\text { book? }\end{array}$ & Yes, she does & No, she does not \\
\hline Did & $\begin{array}{l}\text { Did she go to } \\
\text { school? }\end{array}$ & Yes, she did & No, she did not \\
\hline Has & $\begin{array}{l}\text { Has Jimmy read this } \\
\text { novel? }\end{array}$ & Yes, he was & No, he was not \\
\hline Have & $\begin{array}{l}\text { Have they done } \\
\text { their homework? }\end{array}$ & Yes, they have & No, they have not \\
\hline Had & $\begin{array}{l}\text { Had Lubna eaten } \\
\text { these cookies? }\end{array}$ & Yes, she had & No, she had not \\
\hline To be & $\begin{array}{l}\text { Is he reading a } \\
\text { book? }\end{array}$ & Yes, he is & No, he is not \\
\hline Is & $\begin{array}{l}\text { Am I reading a } \\
\text { book? }\end{array}$ & Yes, I am & No, I am not \\
\hline Am & $\begin{array}{l}\text { Are you reading a } \\
\text { book? }\end{array}$ & Yes, I am & No, I am not \\
\hline Are & \multicolumn{2}{|l}{} \\
\hline
\end{tabular}


A Contrastive Analysis of Interrogative Sentences in English and Indonesian

\begin{tabular}{|c|c|c|c|}
\hline Was & $\begin{array}{l}\text { Was Bobby reading } \\
\text { a book? }\end{array}$ & Yes, he was & No, he was not \\
\hline Were & $\begin{array}{l}\text { Were you reading a } \\
\text { book? }\end{array}$ & Yes, you were & No, you were not \\
\hline \multicolumn{4}{|c|}{ Modal } \\
\hline Will & $\begin{array}{l}\text { Will you come } \\
\text { here? }\end{array}$ & Yes, I will & No, I will not \\
\hline Can & Can you come here? & Yes, I can & No, I can not \\
\hline Shall & $\begin{array}{l}\text { Shall we come } \\
\text { here? }\end{array}$ & Yes, we shall & No, we shall not \\
\hline May & May he come here? & Yes, he may & No, he may not \\
\hline Must & Must he come here? & Yes, he must & No, he must not \\
\hline
\end{tabular}

Table 1.2

Using Expletives "There" and "It" in yes-no questions

\begin{tabular}{|l|l|l|l|}
\hline \multirow{2}{*}{ Expletives } & Sentences & Answers \\
\cline { 3 - 4 } There & $\begin{array}{l}\text { Are there } \\
\text { enough books } \\
\text { in library? }\end{array}$ & $\begin{array}{l}\text { Yesitive } \\
\text { are }\end{array}$ & Negative \\
\cline { 2 - 4 } & $\begin{array}{l}\text { Is there book } \\
\text { on the table? }\end{array}$ & Yes, there is & No, there are not \\
\hline It & Is it your book? & Yes, it is & No, it is not \\
\hline
\end{tabular}

\section{Table 1.3}

Interrogative - Word Questions

\begin{tabular}{|l|l|l|l|l|l|}
\hline $\begin{array}{l}\text { Q- } \\
\text { Word }\end{array}$ & $\begin{array}{l}\text { Helping } \\
\text { Verb }\end{array}$ & Subject & Verb & Answer & Function/asking \\
\hline Where & does & she & live? & $\begin{array}{l}\text { She lives in } \\
\text { Semarang }\end{array}$ & place or position \\
\hline When & will & she & $\begin{array}{l}\text { come } \\
?\end{array}$ & $\begin{array}{l}\text { She will come } \\
\text { at Sunday }\end{array}$ & time \\
\hline Why & do & you & cry? & $\begin{array}{l}\text { My } \\
\text { grandfather } \\
\text { was died }\end{array}$ & reason \\
\hline Who & is & your & $\begin{array}{l}\text { sister } \\
?\end{array}$ & $\begin{array}{l}\text { Ann is my } \\
\text { sister }\end{array}$ & people as subject \\
What & are & you & $\begin{array}{l}\text { doing } \\
?\end{array}$ & $\begin{array}{l}\text { 'm writing a } \\
\text { letter for my } \\
\text { mother }\end{array}$ & Information \\
\hline
\end{tabular}




\begin{tabular}{|l|l|l|l|l|l|}
\hline & is & your & $\begin{array}{l}\text { Fathe } \\
\text { r? }\end{array}$ & $\begin{array}{l}\text { He is a } \\
\text { lecturer }\end{array}$ & profession \\
\hline \multirow{2}{*}{ How } & do & you & $\begin{array}{l}\text { come } \\
\text { here? }\end{array}$ & $\begin{array}{l}\text { I come here by } \\
\text { car }\end{array}$ & $\begin{array}{l}\text { a way to do } \\
\text { something }\end{array}$ \\
\cline { 2 - 6 } & are & you? & - & I am fine & conditions \\
\hline Whom & do & you & see? & I see someone & people as object \\
\hline $\begin{array}{l}\text { Whos } \\
\text { e }\end{array}$ & is & - & $\begin{array}{l}\text { this } \\
\text { book } \\
?\end{array}$ & It's Nancy's & possessing \\
\hline
\end{tabular}

\begin{tabular}{|c|c|c|c|}
\hline $\begin{array}{l}\text { How } \\
\text { far }\end{array}$ & $\begin{array}{l}\text { How far is his } \\
\text { house to school? }\end{array}$ & It is about 1 kilometre & distance \\
\hline $\begin{array}{l}\text { How } \\
\text { long }\end{array}$ & $\begin{array}{l}\text { How long did your } \\
\text { brother cry last } \\
\text { night? }\end{array}$ & He cried for one hour & length of time \\
\hline $\begin{array}{l}\text { How } \\
\text { many }\end{array}$ & $\begin{array}{l}\text { How many books } \\
\text { do you have? }\end{array}$ & I have three books & $\begin{array}{l}\text { the quantity } \\
\text { (countable } \\
\text { nouns) }\end{array}$ \\
\hline $\begin{array}{l}\text { How } \\
\text { much }\end{array}$ & $\begin{array}{l}\text { How much money } \\
\text { do you have? }\end{array}$ & $\begin{array}{l}\text { I have ten thousand } \\
\text { rupiah }\end{array}$ & $\begin{array}{l}\text { the quantity } \\
\text { (uncountable } \\
\text { nouns) }\end{array}$ \\
\hline $\begin{array}{l}\text { How } \\
\text { old }\end{array}$ & How old are you? & I am ten years old & for age \\
\hline $\begin{array}{l}\text { How } \\
\text { often }\end{array}$ & $\begin{array}{l}\text { How often do you } \\
\text { go swimming? }\end{array}$ & Twice in a week & frequency \\
\hline $\begin{array}{l}\text { How } \\
\text { many } \\
\text { times }\end{array}$ & $\begin{array}{l}\text { How many times } \\
\text { does she go } \\
\text { swimming? }\end{array}$ & Once in a week & frequency \\
\hline $\begin{array}{l}\text { How } \\
\text { do you } \\
\text { do }\end{array}$ & How do you do? & How do you do? & $\begin{array}{l}\text { It is used in } \\
\text { introducing each } \\
\text { other }\end{array}$ \\
\hline
\end{tabular}

Table 1.4

Tag Questions in Affirmative- Negative's form.

\begin{tabular}{|l|l|}
\hline Affirmative & Negative \\
\hline You know Mr.John, & Don't you? \\
\hline Smith is reading a & Isn't he? \\
\hline
\end{tabular}


A Contrastive Analysis of Interrogative Sentences in English and Indonesian

\begin{tabular}{|l|l|}
\hline news, & \\
\hline Jimmy can come, & Can't he? \\
\hline
\end{tabular}

Table 1.5

Tag Questions in Negative-Affirmative's form

\begin{tabular}{|l|l|}
\hline Negative & Affirmative \\
\hline You don't know Mrs.Jane, & Do you? \\
\hline Smith isn't writing a letter, & Is he? \\
\hline Jimmy can't drive a car, & Can he? \\
\hline
\end{tabular}

Table 1.6

Tag Questions in equal tenses

\begin{tabular}{|l|l|l|}
\hline Tenses & Main Sentences & Tag questions \\
\hline Past tense & George didn't study hard, & Did he? \\
\hline $\begin{array}{l}\text { Simple present } \\
\text { tense }\end{array}$ & She reads a book story, & Doesn't she? \\
\hline $\begin{array}{l}\text { Present } \\
\text { continuous } \\
\text { tense }\end{array}$ & Jane is cooking a rice, & Isn't she? \\
\hline Future tense & John will tell me a story, & Won't he? \\
\hline $\begin{array}{l}\text { Present Perfect } \\
\text { Tense }\end{array}$ & Jimmy has written a story, & Hasn't he? \\
\hline
\end{tabular}

Table 1.7

Tag Questions with to be "am" in affirmative form

\begin{tabular}{|l|l|}
\hline \multicolumn{1}{|c|}{ Affirmative } & \multicolumn{1}{c|}{ Negative } \\
\hline I am listening the music, & Aren't I? \\
\hline I am a lecturer, & Aren't I? \\
\hline
\end{tabular}




\section{Table 1.8}

Tag Questions with to be "am" in negative form

\begin{tabular}{|l|l|}
\hline Negative & Affirmative \\
\hline I am not reading a poem, & Am I? \\
\hline I am not a student, & Am I? \\
\hline
\end{tabular}

\section{Table 1.9}

The Use of "Let's" in tag Questions

\begin{tabular}{|l|l|}
\hline Main Sentences & Tag Questions \\
\hline Let's go to library, & Shall we? \\
\hline Let's do our duties, & Shall we? \\
\hline
\end{tabular}

\section{Table 1.10}

The use of imperative in Tag Questions

\begin{tabular}{|l|l|}
\hline Main Sentences & Tag Questions \\
\hline Look at the picture, & Will you? \\
\hline Wait a minute, & Will you? \\
\hline
\end{tabular}


A Contrastive Analysis of Interrogative Sentences in English and Indonesian

\section{Table 1.11}

The use of "has" or "have" in tag questions

\begin{tabular}{|l|l|}
\hline Main sentences & Tag Questions \\
\hline Susan has a class, & Doesn't she? \\
\hline John has traveled to Bali, & Hasn't he? \\
\hline
\end{tabular}

\section{Interrogative Sentences in Indonesian.}

(Rhetorical Questions).

Maukah seekor singa memakan rumput? (May a lion eat the grass?)

Akankah seorang koruptor menjadi pahlawan? (Will a corruptor be a patriot?)

Table 2.1

The Pattern of Total and Taq Questions

\begin{tabular}{|l|l|l|l|}
\hline $\begin{array}{l}\text { By adding the } \\
\text { question word } \\
\text { apakah (what). }\end{array}$ & $\begin{array}{l}\text { By adding } \\
\text { partikel }- \text { kah } \\
\text { (suffix }- \text { kah }\end{array}$ & $\begin{array}{l}\text { By changing } \\
\text { the } \\
\text { intonation of } \\
\text { sentence }\end{array}$ & $\begin{array}{l}\text { By adding words } \\
\text { bukan, ya, belum, } \\
\text { tidak. }\end{array}$ \\
\hline $\begin{array}{l}\text { Apakah anda } \\
\text { capek? (Are you } \\
\text { tired?) }\end{array}$ & $\begin{array}{l}\text { Capekkah } \\
\text { anda? (Are } \\
\text { you tired?) }\end{array}$ & $\begin{array}{l}\text { From Anda } \\
\text { capek.(You } \\
\text { are tired) } \\
\text { becomes } \\
\text { Anda capek? } \\
\text { (Are you } \\
\text { tired?) }\end{array}$ & $\begin{array}{l}\text { Anda capek,ya? (Are } \\
\text { you tired, aren't you?) }\end{array}$ \\
\hline $\begin{array}{l}\text { Apakah anda } \\
\text { seorang dokter? } \\
\text { (Are you a } \\
\text { doctor?) }\end{array}$ & $\begin{array}{l}\text { Percayakah } \\
\text { anda kepada } \\
\text { saya? (Do } \\
\text { you believe } \\
\text { in me?) }\end{array}$ & $\begin{array}{l}\text { Kamu seorang petani } \\
\text { bukan?(You are a } \\
\text { farmer, aren't you)? }\end{array}$ \\
\hline
\end{tabular}




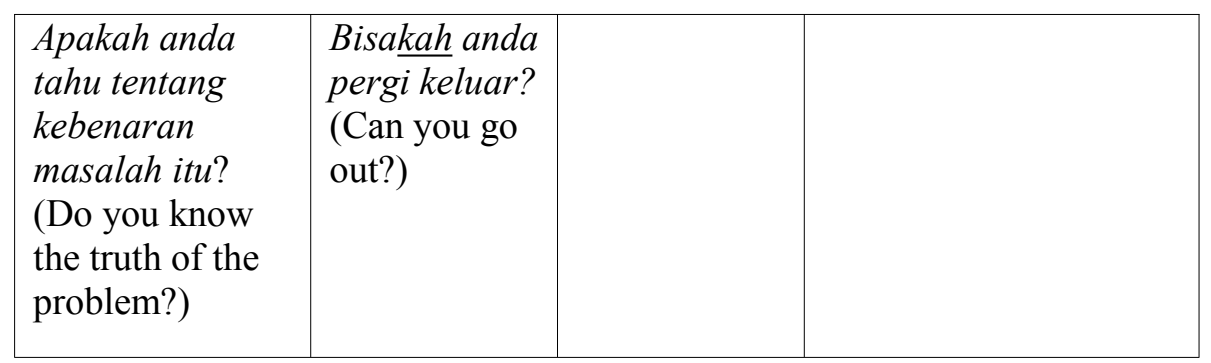

Table 2.2

"Question Words" and Functions

\begin{tabular}{|l|l|l|l|}
\hline $\begin{array}{l}\text { Question } \\
\text { Words }\end{array}$ & Sentences & Answers & $\begin{array}{l}\text { Functions/as } \\
\text { king }\end{array}$ \\
\hline $\begin{array}{l}\text { Siapa, } \\
\text { untuk siapa, } \\
\text { kepada } \\
\text { siapa,dari } \\
\text { siapa. } \\
\text { (Who) }\end{array}$ & $\begin{array}{l}\text { Siapakah anda? } \\
\text { (Who are you?) }\end{array}$ & $\begin{array}{l}\text { Saya adalah saudara } \\
\text { Bob. } \\
\text { (I am bob's brother) }\end{array}$ & people \\
\hline $\begin{array}{l}\text { Apakah, } \\
\text { Apa, dari } \\
\text { apa, untuk } \\
\text { apa, dengan } \\
\text { apa } \text { (What) }\end{array}$ & $\begin{array}{l}\text { Apa yang kamu } \\
\text { lakukan?(What } \\
\text { are you doing?) }\end{array}$ & $\begin{array}{l}\text { Saya sedang membaca (I } \\
\text { am reading ) }\end{array}$ & object \\
\hline $\begin{array}{l}\text { Berapa } \\
\text { (How) }\end{array}$ & $\begin{array}{l}\text { Berapa banyak } \\
\text { buku yang anda } \\
\text { punya?(How } \\
\text { many books do }\end{array}$ & $\begin{array}{l}\text { Saya mem-punyai 3 buku } \\
\text { (I have three books ) }\end{array}$ & quantity \\
you have?) & $\begin{array}{l}\text { Dari mana } \\
\text { anda berasal? } \\
\text { (Where do you } \\
\text { come from?) }\end{array}$ & $\begin{array}{l}\text { Saya berasal dari Medan } \\
\text { (I come from Medan) }\end{array}$ & place \\
\hline $\begin{array}{l}\text { Dimana, } \\
\text { kemana, } \\
\text { darimana } \\
\text { (Where) }\end{array}$ & $\begin{array}{l}\text { Kapan anda } \\
\text { pergi? } \\
\text { (When do you } \\
\text { go?) }\end{array}$ & $\begin{array}{l}\text { Saya pergi kemarin } \\
\text { malam } \\
\text { (I went last night) }\end{array}$ & time \\
\hline $\begin{array}{l}\text { Kapan, } \\
\text { bilamanana } \\
\text { Apabila, } \\
\text { bila } \\
\text { (when) }\end{array}$ & & \\
\hline
\end{tabular}


A Contrastive Analysis of Interrogative Sentences in English and Indonesian

\begin{tabular}{|l|l|l|c|}
\hline $\begin{array}{l}\text { Bagaimana } \\
\text { (How) }\end{array}$ & $\begin{array}{l}\text { Bagaimana } \\
\text { kabar anda? } \\
\text { (How are you?) }\end{array}$ & $\begin{array}{l}\text { Saya baik-baik saja } \\
\text { (I am fine) }\end{array}$ & situation \\
\hline $\begin{array}{l}\text { Mengapa } \\
\text { (Why) }\end{array}$ & $\begin{array}{l}\text { Mengapa anda } \\
\text { datang } \\
\text { terlambat? } \\
\text { (Why do you } \\
\text { come late?) }\end{array}$ & $\begin{array}{l}\text { Karena saya membantu } \\
\text { (Because I help my } \\
\text { mother) }\end{array}$ & reason \\
\hline
\end{tabular}

\section{Discussion}

The language learners face difficulties in learning foreign language because they tend to transfer the SL into the TL. Brown (2007:272) said the main obstruction of second language acquisition is the interferences system of first and second language. The interferences between two languages occur because they have similarities and differences. The researcher analyzes it based on the grammar features and the use of both of languages.

At first, three kinds of questions exist in both languages; they are Yes - No (total questions), Interrogative - Word (partial questions) and Tag Questions. The speakers of both languages use this to see whether the information is correct or not. Secondly, words questions in English are equivalent to words questions in Indonesian. They are used to ask for information of people, facts, events, time. Both of them use interrogative pronouns, which are equivalent. For example, who $=$ siapa, what $=a p a$, When=kapan, Where=dimana, Why=kenapa, and How=bagaimana . These interrogative words can be used as questions in two languages. Question words which are used in both languages have the same functions in sentences for asking the things, places, times, reasons, 
people, and conditions or ways to do something. Thirdly, both languages have the same strategy to compose interrogative sentences which has functions to reemphasize that the message delivered are 'correct', that is by asserting the statement of sentences. In English, it is called as "tag questions" (Elan, 2005:139). In Indonesian, these questions are indicated by the word "bukan" in the end of sentences (Muslich: 1990:135).

However, there are remarkable differences between them. First, they differ in the way the interrogative form is formed. We put the question word at the beginning and at the end of sentences in Indonesian. Secondly, in terms of the forms of interrogative sentence, they have different pattern. In English, they are formed based on the interrogative pattern. The verb in questions is handled differently depending on whether the verb is or is not accompanied by an auxiliary in declarative sentences. In Indonesian, interrogative sentences can be formed by declarative sentence by changing the rising pitch of sentence. Unlike English, the word order is not changed and we have no auxiliary verb to be used according to the tense of the sentence whereas in English, we need to change the word order, insert auxiliary verbs on the basis of the tense of the sentence.

Thirdly, in terms of the 'use' of question word of who ( siapa), In English, interrogative uses question word of "who" for asking subject or object and "whom" is merely used for asking object. When "who" is used as subjects, it is followed by an affirmative verb and as objects of a verb and object of preposition. While, in Indonesian, the word "siapa" (who) can be used for subject or object.

Fourthly, the tags of tags questions in English always formed 
A Contrastive Analysis of Interrogative Sentences in English and Indonesian

from the main clause and have the opposite forms of auxiliary verbs, model verbs, and to be the grammatical rule of tags questions in English is generally complex. The question tag for "I am" is "aren't I" (Swan, 2000, p. 480). For example: I'm late, aren't I. Tags questions in English are also used for imperatives and suggestions. However, this kind of tags question has no equivalent in Indonesian.

\section{Conclusion}

Concerning the similarities and differences mentioned above, the following predictions are derived from the contrast of two languages in terms of making questions: due to the facts that questions in Indonesian and English have many common features, Indonesian learners of English can make some positive transfer to produce the question in the target language easily. For example, when making questions to ask for information, students can apply variable question forms.

Therefore, when teaching question form, teachers can translate directly English to Indonesian in order that students can understand the grammar points. However, the differences between the two languages in question, may lead learners of English to make some errors. The most common errors they may encounter are due to the form of interrogative sentences. There are some rules for making interrogative form in English that do not exist in Indonesian. Such as the inversion of auxiliary verbs, model verbs and to be, using do and does when there is no auxiliary. As a result, the students may construe do as an equivalent for word questions and use it along with auxiliary and modal verbs. Another problem may emerge 
from transferring the structure of words questions in Indonesian to English. As mentioned before, wh-movement is optional in Indonesian whereas it is obligatory in English. Additionally, lacking the knowledge of when to use or not to use do after interrogative word is another area problem for Indonesian learners English. When interrogative word is the subject (or part of the subject), the question word comes before the verbs and do cannot normally be used. On the other hand, when the question word is the object, do is used. So, an ungrammatical sentence may be used due to the lack of knowledge (Zhang Wang, Wu \& Huo, 2011). Another problem concerns with tag questions in English, it has various patterns based on the tenses of affirmative sentences' form. These are equal tenses between main sentences and taq-question. In Indonesian, this is only use "Bukan", for all of affirmative sentences' form. The students may apply this rule in English and make an equivalent for these words and phrases.

In brief, this paper aimed to have an overview of interrogative structures in Indonesian and English to explore the similarities and differences between them as well as making some predictions based on these similarities and differences. Although this is just one of the aspects of contrastive analysis, it may help teachers as well as their students overcome some difficulties they have encountered and improve their English language teaching and learning regarding the formats of questions in English and Indonesian languages from CA perspectives. 
A Contrastive Analysis of Interrogative Sentences in English and Indonesian

\section{References}

Azar, Bety Schrampfer. (1941). Fundamentals of English Grammar.

New Jersey: Prentice Hall International.

Biber, D., Johansson, S., Leech, G., Conrad, S., \& Finegan, E. (1999).

Longman grammar of spoken and written English. Harlow: Pearson Education

Brown, H.D. (2007). Principles of Language Learning and Teaching. $\left(4^{\text {th }}\right.$ ed.). New York: Longman

Cheng, L, Watanabe,Y., \& Curtis, A. (2004). Wash back in language testing. London: Lawrence Erlbaum Associates, Publishers.

Frank, Marcella. (1972). Modern English a Practical Reference Guide. New Jersey: Prentice Hall.

Gorjian, B., Pazhakh, A., \& Naghizadeh, M. (2012). Comparative Study of Conjunctive Adverbials (CAs) in Native Researchers' (NRs) and Non-Native Researchers' (NNRs) Experimental Articles. Advances in Asian Social Science, (1), 244-247

Keraf, Gorys. (1991). Tata Bahasa Rujukan Bahasa Indonesia. Jakarta:Grasindo.

Muslich, Masnur. (1990). Garis-Garis Besar Tata Bahasa Baku Bahasa Indonesia. Malang: Yayasan Asih Asah Asuh.

Newmark, P. (1988). A textbook of translation. Hertfordshire: Prentice Hall. 
Schackne, S. (2002). Language teaching research: In the literature, but not always in the classroom. Journal of Language and Linguistics, $1,1-11$.

Swan, M. (1995). Practical English Usage. Oxford: Oxford University Press.

Webber, P. (1994). The function of questions in different medical English genres. English for Specific Purposes, 13, 257-68.

Zhang, Y, \& Wu, L. (2008), Weights optimization of neural network via improved BCO approach. Prog., Electromagn. Res., 83, 185-198. 
A Contrastive Analysis of Interrogative Sentences in English and Indonesian 